IDEA - Studia nad strukturą i rozwojem pojęć filozoficznych $\mathrm{XXIX/2}$ Białystok 2017

\author{
Wilson Eze Ehianu \\ (Benin, Nigeria)
}

\title{
AN ANALYSIS OF CHURCH AND STATE ROMANCE BETWEEN MAY 1997 - 2007 DEMOCRATIC ERA IN EDO STATE, NIGERIA
}

\section{Introduction}

Edo State was created on August 27, 199I by the military government of Ibrahim Babangida. It was excised from Bendel State which was carved out from the defunct Western Region in 1963 sequel to a referendum taken in the area, (Office of the Governor, 2001:4). With a population of 3,218,332 spread across eighteen local government areas, it is one of the states distinguished by relative homogeneity of its people in the sense that almost the same cultural and linguistic affinities exist among the various groups (Vanguard Jan. 10, 2007:1). European contact with the people of Edo began as early as the fifteen century (Nwosu 1998:1) However, effective evangelization of the area took place in the second half of the nineteenth century through the activities of Christian missionaries of different hues. These were the Roman Catholic Missionaries, the Church Missionary Society known by the acronym C.M.S. which founded the Church of England, the Anglican Communion, the Baptist, the Methodist, and the Presbyterian Church Missionaries (Ehianu 2007:1) Of these, the Roman Catholic Church (hereinafter referred to as RCC) had a population of 250,000 as at 1996, thus, making it the largest single denomination, apart from (the Pentecostals if grouped together (The Catholic Archdiocese of Benin City, 1996:51). 
In the 1970s, a quiet religious revival in America spawned the Pentecostal and Charismatic movements'. Prominent among these in Edo State are: Church of God Mission, founded by the late Archbishop Benson Idahosa, St. Joseph's Chosen Church of God, by Apostle Joseph Ikechukwu, Christ Chosen Church of God, (a splinter group from St. Joseph's Chosen Church of God) Assemblies of God Church, Christ Apostolic Church and numerous others.

There exist also the second generation Pentecostal groups, notable among which are: The Redeemed Christian Church of God, Living Faith, Christ Embassy to mention but a few. These groups which have become well entrenched in Edo State by virtue of their resilience are characterized by the phenomenon of extreme atomization. Hence their number cannot be ascertained.

In addition, there are also Millenialist groups like the Jehovah's Witness and the Seventh Day Adventists. While there is a preponderance of Christian population in sixteen out of the eighteen local government areas, the same cannot be said of the other two where seemingly, there is a parity of Christian/Muslim population. The native religion of the people, though commanding large adherents, appears to have been relegated to the background as it is hardly represented in government schemes. For instance, the adherent's are neither sponsored on pilgrimage to their holy sites nor is there provision for their pattern of prayer in official meetings.

The various religious groups in Edo State, especially Christians and Muslims, in their quest for converts have been known to employ strategies which at times do not encourage peaceful 'co-existence among the people. These include, unsolicited congratulatory messages/praise singing and alliance with the government of the day in a bid to gain prominence and undue advantage over other groups in the land (Ehianu, 2010:18). The size and influence of the Christian Churches and their ecumenical groups in Edo State place them in such a crucial position that they cannot be ignored by any democratic regime. The interaction between the church and state during the Lucky Igbinedion era, May 1999 - May 2007 is the, focus of this study. Reference may be made to events outside this period for the purpose of comparism and emphasis. But first, a word on the political trajectory of Edo State prior to May, 1999. 


\section{Political Background of Edo State}

Until May 1999, the military was a cog in the wheel of democratic governance in Nigeria, its intrusion into the politics of the nation resulted to its domination of the political space and imposition of arbitrary rule for an aggregate period of 29 years out of the nation's 47 years of existence (Asemota, 2000:2). As with most military regimes where their administration was unitary, authority was centralized at the national level; Administrators were appointed for the component states by fiat; as one coup was frequently superseded by another; state administrators were replaced according to the whims of the Commander in Chief.

Fortunately, the government of General Abdulsalami Abubakar on $29^{\text {th }}$ May, 1999 bowed to pressure which came from the Church, Civil Society Groups, Labour Organizations and International Community when he returned the country to civil rule (Ehianu, 2008:196). As Chief Olusegun Obasanjo was being sworn-in as President in Abuja, the nation's seat of government, state governors were receiving the mantle of leadership at state levels. Chief Lucky Igbinedion (son of a wealthy businessman in the State) emerged as the governor of Edo State on the platform of the Peoples Democratic Party (PDP) after defeating his closest rival, Lucky Imasuen of the All Peoples Party (APP). Thus, Igbinedion was to steer the ship of the state for the next four years. The governor was well aware that for his administration to have a smooth sail, he needed the support of two principal institutions viz the traditional institution of which the Oba of Benin was the most powerful and the State branch of the Christian Association of Nigeria (CAN), and amalgam of five ecumenical groups - the Catholic Church, the Christian Council of Nigeria (mainly Protestant Churches), the Organization of African Instituted Churches (OAIC), the Pentecostal Fellowship of Nigeria (PFN) and the Evangelical Church of West African (ECWA), (CAN CONSTITUTION 2004:2). Of these blocks, the Roman Catholic Church was the most influential. The pre-eminence of the Catholic Church does not lie in it numerical strength alone, or the caliber of it's membership, nor on its formidable hierarchical order, but more on its political conscientization programmes and dogged commitment to democracy, rule of law. justice and good governance. Though a Baptist the governor had earlier in his campaign promised that if he won the election, his thanksgiving service would be at St. Albert's Catholic Church, Ugbowo in the state capital. This promise the governor 
fulfilled when on $18^{\text {th }}$ July, 1999, he was at St. Alberts Catholic Church accompanied by top government officials, friends and political associates to thank God for giving him victory at the polls (The Observer July 19,1999:1). The governor was full of thanks to all who had thrown their weight behind him during the election and sued for support for his administration. He particularly thanked Rev. Fr. Theophilus Uwaifo, whom he described as "'a man of God and strength" (The Observer July 19th 1999:1). Uwaifo who incidentally was the officiating priest lauded Igbinedion for coming to the church to fulfill his promise. Subsequently, the governor appointed this Catholic Priest Pro Chancellor and Chairman of Governing Council of the State owned University. A position he occupied throughout the governor's two terms of four years each.

The following Sunday, the governor was at the Central Baptist Church for another thanksgiving which coincided with his wife's $40^{\text {th }}$ birthday anniversary. As usual, he thanked God for his victory at the polls and the church for standing behind him with a promise to assist the church to the best of his ability. Responding to the governor's appreciation, the pastor in charge confessed:

We prayed for good President, prayed for Edo State
not to be in opposition and prayed to God to crown
Lucky Igbinedion's mission of becoming a governor
with success and all these have being achieved...

(The Observer Aug. 7, 1999:1).

Meanwhile, the previous day, the governor was at the Church of God Mission, arguably the foremost Pentecostal Church in the State, to close the 1999 Christian Women Fellowship Convention which was earlier opened by his wife, Eki Igbinedion. He sued for the co-operation of the women in what he called "the task, of moving the state forward" (Office of the Governor 2001:58). For his rapprochement with the Church, the number one man in the State was made an honorary deacon of the church (Orobator -2007).

Expectedly, the state was agog with praise songs, especially from the pentecostal pastors who saw in the governor, an opportunity to enhance their personal ego and the image of their church. The governor was the guest of honour at many church programmes and these were given wide publicity in the electronic and print media. Where he could not attend in person, he sent representatives. 
According to Okhuedoba, the Secretary of CAN, Edo State, realizing that a, common front would yield more fruits for the churches themselves and the state in general, the organization presented the church's demand to the state government which included inter alia, improvement on health, education, road maintenance, security and general welfare of the citizens. These requests. Okhuedoba said, the governor promised to make the crux of his administration (Orobator 2007:Ibid). Sometime in 2002, the governor at a visit to a botanical garden and orchard, managed by the Catholic Monastery at Ewu made a grant of one million naira to the centre on behalf of the State government to boost its expansion program me (Ebianu 2007:91). Similarly, the governor's father Gabriel Igbinedion donated a church building to the Catholic Church, which he lobbied the authority to name after St. Gabriel, a name he shares with the $\mathrm{Ca}-$ tholic Saint.

These gestures among others have been variously interpreted. To some persons, the governor wanted to impress the Catholic Church where songs in his praise were not so loud. Others, like Orobator see the gestures as ordinary token, which could have come from anybody in appreciation and encouragement to the church for its activities in nation building .Still to many, the governor merely played to the gallery (Orobulor 2007:Ibid).

In 2002, there were series of kerosene explosion. Many died and most survivors had varying degrees of deformity. According to Rev. Fr. Ogbonmwan, delegations were sent under the auspices of CAN to the Nigerian National Petroleum Company (NNPC) which was believed to have supplied the adulterated kerosene and to the state government requesting them to show greater commitment to the plight of victims. Subsequently, the state government financed reconstructive surgery on some of the victims of the accidents (Ogbonmwan, 2005).

Irked by what they called the marginalization of Muslims in the state in political appointments, the executive council of National Supreme Council for Islamic Affairs (NSCIA), Edo State branch, led by the Chairman Alhaji Braimoh Abuda paid a protest visit to the State House where they had audience with the state governor. The governor absolved himself of the charges of marginalizing the Muslims in his schemes of things and revealed that those who were appointed were individuals recommended by the local government authorities. In a bid to sooth their nerves, the governor requested the Muslim community to 
furnish his office with names of qualified and capable Muslims for appointment in boards and parastatals in the State (The Observer June 28, 19:8).

The relationship between the Church and Edo State Government towards the end of 2002, depict" how the dissonance between expectations and reality, could lead to conflicts. There were signs that the initial zeal and performance of the government were not sustained. Hope of improved infrastructure and morale of workers was being replaced with disillusionment as salaries were not paid as at when due. Government pensioners were owed their entitlements for as long as one year. In fact, some aged pensioners slumped and died while queuing to collect their pension because of the harrowing bureaucracy. The situation was made worse by the premature mass retrenchment in the civil service. Besides, the government was accused of corruption, which belied earlier promises of transparency, accountability and efficient management of state resources. Disenchantment with the governor and his administration aggravated when it became a policy of the Federal Government to publish monthly allocations to States. Comparing the State's monthly receipt from the Federal Government, and the internally generated funds, with what was on ground; many felt the people weren't deriving value for their money. Consequently, the governor found himself running against the tide of public opinion. The administration found cassus belli in the fact that it inherited huge debt burden from the past administrations and that this money was being deducted from source by Federal Government. The result, the government surmised, was that the funds accruing to the State were inadequate to execute government programmes. The people wanted infrastructural development and improved standard of living and so, will not brook excuses.

In a manner reminiscent of Jesus Christ, those who a few years shouted Hosanna joined forces to demand for the governor crucifixion. Even church leaders who had earlier mobilized their followers in support of the governor soon realized that the governor had ceased to be an asset -and so aligned with their faithful to lament the calibre of leader the state had.

In 2002, there was an upsurge in violent crimes especially armed robbery in the state. The Christian Association of Nigeria came up with a communique with the caption: "Edo State Under Siege". The release chronicled incidents of unresolved crime in the state and called on the governor to do his job of protecting lives and properties. The governor who was uncomfortable with the $\mathrm{Chu}-$ rch's volte face insisted that leaders of CAN should have sought audience with 
him and not castigates his government on the pages of newspapers. Even though the Governor was dissatisfied with the publication, it nevertheless served as wakeup call. This is because certain measures were taken to stem the tide of crime in the state. For instance, the use of motor bicycle for commercial transportation after $6 \mathrm{pm}$ was banned. This followed reports that most robberies in the state were carried out by men whose means of escape was motor bicycles (Okbuedoba 2007). Furthermore, special unites of the police such as State Anti Robbery Squad (SARS) and the Rapid Response Unit were established to combat crime in the state.

Another effort to fight crime in the state was the proposal to establish what was called "Neighborhood Watch", a form of community vigilante outfit to collaborate with the police to fight crime. Though CAN appreciated the motive, the body expressed fears and reservations that such an outfit might be hijacked and used to harass political opponents. In a letter addressed to the Stale House of Assembly. CAN requested that the bill which had been sent to the House be stepped down with an advice to the government to devise other strategies in its war against crime. Of course, the Christian body had its way as the bill could not scale through. The fight against crime yielded fruits with a significant decline in crime rate, a situation which according to Okhuedoba prompted CAN to write a commendation letter to the governor in acknowledgement of his effort in crime prevention.

The four years tenure of the governor ended on the $29^{\text {th }}$ May, 2003, But the proceeding months were laced with intrigues and innuendoes. Putting his power of incumbency to optimal use, Igbinedion obtained his party's ticket to seek re-election for another term of four years. As the government was trailed by accusations of non-performance, there were many in the party who were uncomfortable with the choice of the governor as the party's flag bearer. The churches under the canopy of CAN felt that- the governor could have performed better. In fact, it became a cliche that the State was unlucky to have Lucky for a governor. Public opinions converged on the fact that only through rigging will the party remains in power and this, many, including church leaders were set to checkmate. In its determined effort to ensure that only credible leaders emerged victorious at the polls, CAN organized an informal screening for governorship aspirants. According to Okuedoba, the Secretary of the Association, sixteen aspirants were invited out of which six turned up for the exercise. Four of these people were found suitable and consequently recommended to the churches for 
support. On why CAN did not adopt a particular candidate, Okhuedoba said, since the association consists of five blocks of churches, such a move could polarize the association. CAN, he said, does not impose candidates on people but ensure that whoever was elected into leadership position governed with the fear of God and raise the living standard of the people. Prayers were offered to the effect that only men who had the interest of the people at heart emerged as winners (Okhuedoba 2007).

As the elections drew closer, the state commissioner of the country's electoral body-Independent National Electoral Commission (INEC), Mr. Daniel Etukudor in what was a show of confidence in CAN invited the association to partner with him as he performs his job. CAN was requested to nominate Adhoc staff for the commission and to observe the elections. Accordingly, the Christian body sent out letters to member churches asking for nominations. Nominees were received and training organized for those selected. The church was poised to have a credible election which had eluded the state for too long. But this was not to be as the INEC commissioner Etukudor was replaced with Alhaji Shehu Lawal, a few weeks to the elections. The new boss jettisoned the accord his predecessor had with the Christian association.

A new list of adhoc staff which was believed to have emanated from politicians was drawn. Thus, fears were expressed concerning the credibility of the elections. There were allegations that the ruling party in the state which was controlled by the Federal Government masterminded the redeployment of Mr. Daniel Etukudor in order to facilitate rigging.

Expectedly, campaigns were intensive. The leading opposition candidate, Senator Rowland Owie of the All Nigerian People Party (ANPP), a Catholic, tried all he could to secure the support and sympathy of the Catholic Church by .employing catholic symbols and usages, such as the rosary, our mother Mary and regular visit to Catholic parishes and institutions. Of course, he was able to sway the sentiment of some Catholic faithful even though Orobator avers that given his antecedence, he could not convince many Catholics, neither did the Catholic Church give him official support. When told that some priests asked their faithful to vote for a candidate whom they called their brother, that is Owie, Orobator affirmed that "such priests merely expressed their opinion, the church did not take a position on that" (Orobator, 2007).

As the governor was not sure of the support of the Catholic Church, he turned to the Pentecostal groups, which as earlier said, when put together, out- 
number all mainline churches. For instance, during the $8^{\text {th }}$ day convention of the Voice of Freedom Ministries, the governor, who was in attendance, urged the congregation to vote enmass for his party at the polls claiming that the party had done well within the available resources to improve the welfare of people in the State (The Observer, March 10, 2003: /).

Though CAN had been tactfully schemed out of the electoral processes, some of their members, including CAN Secretary, went into an alliance with the Justice Development and Peace Commission (JDPC); an organ of the $\mathrm{Ca}^{-}$ tholic Church, to monitor the elections in the state. Both the local and international agencies which observed the April $19^{\text {th }} 2003$ pools reported that the elections were marred with irregularities (Orobator, 2007).

Notwithstanding, the incumbent governor was declared winner amidst controversies. Meanwhile, the Observer team led by Yesufu had prepared their report, which was duly signed by Yesufu, awaiting publication. The governor, sensing that the report, if published, will accentuate the ground well of opposition against him quickly offered Yesufu an appointment in the Government House. When the report was eventually published, Yesufu denied being a party to the entire process to the astonishment of those concerned. Of course, some members of the group did not see anything wrong in Yesufu's action, stressing that as an individual, he was free to change his mind on an issue.

To Rt. Rev. Edionwe, Yesufu's action was condemnable because in his words "Yesufu ate his vomit" (Orobator 2007). The interaction between church and state during Igbinedion second term in office as governor witnessed policy modification from both sides. The church which was implicitly against the governor's re-election could not identify with the government and so adopted a "siddon look attitude". The governor, knowing he may not canvass for anyone's votes again (the country's constitution permits only two terms for executive positions) ignored the church to address other issues, prominent among which was the crises within his party which had culminated in the impeachment of the speaker of the house, a move the governor feared was to facilitate his removal from office.

Perhaps to prove he had nothing against the church, the governor acceded to an earlier request by the church when on the $18^{\text {th }}$ of May, 2004, through his Education Commissioner, Lucky Omagbon announced the return to former missionary owners, three selected secondary schools which had been lost to government's secularization policy over thirty years ago.. The decision, adjudged a 
watershed in the history of education in the state elicited varied reactions from the public. On the one hand, there were those who saw in the policy, a practical solution to the declining standards of education in the state and the country in general. On the other side of the divide, were those who accused the government of shying away from its social responsibilities (Ehianu 2006:204). The churches to which schools were returned were happy though the gesture did not translate to significant improvement in church and state relationship as only three churches benefited. Besides, given the number of schools lost by the missions, the return of one each to three churches was nothing to cheer about.

One thing was discernable from the attitude of church leaders in Edo Stale to the governance and development in the state. The governor had failed and the state must wait a little longer for the political messiah.

\section{Observations and Recommendations}

While one is impressed with the courageous and vocal stand of individual Christians and the Christian Association of Nigeria, Edo State Branch, one is also alarmed by the shamelessness, sycophancy and betrayals exhibited by some clergy and influential Christians in Edo State. Orobator was quick, to disassociate the Roman Catholic, Archbishop (Emeritus) of Benin City, Rt. Rev. Ekpu from what he called booth licking clergy. He enthused that Ekpu never honoured any invitation in person from the governor. To Orobator, the relationship between the governor and Ekpu was a cautious one unlike the Pentecostal pastors for whom, he said, the boundaries were very fluid (Orobator 2007). The study brings to the fore, effort of the government to secure the support of the church by dangling some carrot before them and where this was unsuccessful, divide and rule strategy was employed, with the result that the old denominational acrimony and rivalry was rekindled.

Worthy of note is the fact that every Christian denomination not only celebrate when its faithful occupies an influential political office but tends to ward off other Christian groups. This is clone through massive publicity of the office holders engagements with the church and by, inducting him/her into church offices. For instance, the present governor of the slate Adams Oshiomhole got more than he bargained for during $a$ thanksgiving service at St. Paul's Catholic Church Benin City where he was invested and commissioned an usher in the 
church, an offer the governor accepted but said he could only occupy effectively when he leaves office as governor of the state. The church administration acknowledged that:

The Oshiomhole led administration in her usual generosity and respect for the church donated heavily for evangelization in rural areas. That was not the first or will it be the last that CATHOLICS enjoy these benefits simply because the governor is our own (Akpata, 2014:4).

Perhaps to invoke the envy and jealousy of other Christian groups in Edo State, the church revealed:

It is wonderful to note that Edo State is presently under the leadership of the Catholic Church and will continue. Are you aware that Gov. Oshiomhole, his deputy, Dr Odubu, the speaker of Edo Slate House of Assembly, Hon. Philip Shuaibu and a host of others are chronic, zealous; ardent and positive fanatic communicants in the Catholic Church? This is wonderful (Akpata, Ibid).

Such an attitude makes it difficult for the Christian church to be an effective check on the excesses of government and to act as the moral compass of the society as stipulated in Matthew 5: 14-16.

In any case, the relationship between church and state in most societies where the former is entrenched and free, is often a symbiotic one, though conflicts are never ruled out. The same is true in Edo State, Nigeria, The church contributes to the development of the state and indeed nation building through its educational, medical and political conscientization and mobilization programme. Individual churches and CAN have programmes, which are aimed at alleviating poverty through the impartation of skills and disbursement of loans to Christians and non Christians alike. To that extent, the church and state are fellow stewards in God's vineyard, the world.

However, the church in Edo State has to a considerable extent, failed to give-moral leadership. The body of Christ which was supposed to be a bastion of morality was found to be wanting. Many members of the clergy and laity exhibit the same love for money as the politicians and have been adjudged birds of the-same feathers. Consequently, when they speak up against vices in the society, they are not taken seriously. The church must make deliberate effort to 
purge itself, if it must enjoy the respect and honour of the secular society. This will involve ethical re-orientation, respect for the dignity of every human being, contempt for wealth not created from identifiable quest, transparency and accountability at every level of its hierarchy. The clergy must show greater commitment to the welfare of their members and eschew extravagance which further alienates them from their flock.

For effective prophetic witnessing, the church necessarily needs to set up some organs and strategies of active involvement from where the true picture of issues in the state could be sufficiently and undilutedly relayed. Such strategies or organs should include a monitoring group, legal and media committees (Oyibo 1998:8). Greater unity among the churches in Edo Slate will put them in better stead to influence government policies and programmes Drawing inference from history, we must add that neither indifference nor partisanship of the church with secular authorities is in the best interest of the church, but certain steps are necessary. Churches and ecumenical organizations must raise the level of political consciousness in the state through seminars, conferences and debunking erroneous views concerning the church and politics (Imasogie 1996:27).

Secondly, there must be education for Christians on their social responsibilities to transform the society. Thirdly, there is need for regular rapport with Christians in the corridors of power in government, industries, economy and academics. Fourthly, there should be periodic representation to government officers whose actions shape societal ethos (Imasogie 1996.28). Indeed. Christians must act as leaven and spiritual catalyst to transform society and thereby entrench and magnify Christ as the all sufficient changer of men and society.

\section{Conclusion}

The history of the Christian church and secular authorities now as before is replete with conflicts and co-operation. Between 1999-2007, the Christian church made effort to serve as a check on the government. For instance, the church helped to forestall the creation of a local vigilante group which many feared might become an instrument of oppression and intimidation of political opponents. 
The study equally bring to the fore the fact that Christian churches and the clergy in particular could hardly speak with one voice even in matters of importance to the generality of the citizenry due in part to pecuniary interest. Christian churches in Edo State must put their house in order if they are to serve as light of Edo State and indeed the country in general.

\begin{abstract}
This paper investigates the relationship between the Church and the State with particular reference to Edo State Government of Nigeria during the Lucky Igbinedion era - May 1999 May 2007. Applying the tools of historical and phenomenological research, the work reveals attempts by the government to manipulate the Church to feather its political nest by courting the friendship of Church leaders who were believed to command the obedience of their followers. The study shows that some clergy engaged in praise singing for the government in order to enjoy patronage and be identified with the cream of the society, the political class in particular. While this paper does not suggest political apathy among Church leaders, it calls for caution as exposing the Church to the vicissitude of politics could derail it from its avowed mission - the salvation of souls.
\end{abstract}

Key words: church, state, politics, crisis, peace

\title{
Bibliography
}

Akpata, M. (2014). "Evangelism triggered in St. Paul's Parish as Gov. Oshiomhole Becomes a church Warden" The Evangelist Vol. 20. No. 15.

Asemota, S. A. (2000) "The People and Democracy in Nigeria 1960-2000" An Address Presented at the Holy Cross Cathedral Benin City, Benin City: Floreat Systems.

Ehianu. W. E. (2007) "Ecumenism in Benin and Environs in the Light of Vatican II's Unitas Redintegrdtio, 1965-2005", Unpublished Ph.D. Thesis, Ambrose Alli University, Ekpoma.

Ehianu. W. E. (2007) "The Church and Agricultural Development in Nigeria" in BIUDISCOURSE, Journal of Arts and Education. Benson Idahosa University, Benin City, Vol. 2, No. 1

Ehianu, W, E, (2006) "Return of Mission Schools to Former Owners, An Aspect of '..Church History in Edo State"' in E: O. Oyelade (ed.) Readings in Religion and Philosophy, Benin City: Teredia Publications.

Ehianu, W, E, (2010) "The Challenges and Prospects of Ecumenism in Nigeria in The International Researcher. Vol. 1. No 5

Imasogie, O. (1996) "The Role of CAN in Confronting Corruption in a Permissive Society". Proceedings of 1996 Plenary Session of CAN, Benin City, Floreat Systems.

Nwosu, L.U. (1998) The Religious factor in the History of West Africa, Owerri: Vivian and Vivian's Publishers.

Office of the Governor, (2001:4) The Lucky Touch, Benin City: Printing and Packaging ;Aids. 
Ogbomwan, F. (2005) Personal Interview, Parish Priest, Holy Spirit Catholic Church, Benin, Member, CAN Executive Council, Edo State, C. 57yrs.

Okhuedoba, C. (2007) Personal Interview, Administrative Secretary, CAN Edo Stale Branch, Benin City, C. 55yrs.

Orobator, M. (2007) Personal Interview, Chairman Christian Social Movement of Nigeria (CSMN), C. 55yrs, Benin City. For more information see, The Guardian. May 16, 2003:56.

Oyibo, T. B. (1998) "The Riddle of Democracy in Nigeria". The Voice No. 37. See also The Catholic Archdiocese of Benin City, (1996:51) The Church of Benin City, Benin City: Floreat Systems.

Wilson Eze Ehianu (Ph. D) - Department of Philosophy and Religions, Faculty of Arts, University of Benin, Benin City 